\title{
Pengembangan LKPD Berbasis Model Pembelajaran AIR Berorientasi Pada Peningkatkan Kemampuan Komunikasi Matematika
}

\author{
Atika Nur Hidayati $^{*}$, Alben Ambarita ${ }^{2}$, Dwi Yulianti ${ }^{3}$ \\ 1,2,3 Program Studi Magister Keguruan Guru Sekolah Dasar, Universitas Lampung, Indonesia \\ *atikanurhidayati64@gmail.com
}

\begin{abstract}
Abstrak
Dari hasil penilaian jawaban tes kemampuan komunikasi matematika serta penyebaran angket diperoleh permasalahan yaitu rendahnya kemampuan komunikasi matematis peserta didik, sulitnya peserta didik untuk menuliskan bentuk simbol-simbol matematika serta keterbatasan bahan ajar yang digunakan saat pembelajaran di kelas V di Sekolah Dasar. Penelitian ini bertujuan untuk mengembangkan lembar kerja peserta didik (LKPD) pada materi bangun ruang sederhana di kelas V Sekolah Dasar yang valid, mengetahui kepraktisan LKPD dari pengguna yaitu pendidik dan peserta didik, serta mengetahui keefektifan LKPD yang dikembangkan terhadap peningkatan kemampuan komunikasi matematika. Metode penelitian pengembangan yang digunakan dalam penelitian ini mengacu pada desain penelitian Borg and Gall. Teknik pengumpulan data dilakukan melalui dokumentasi, observasi, angket dan tes kemampuan komunikasi matematika peserta didik. Subjek penelitian ini yaitu 25 peserta didik kelas kontrol dan 25 peserta didik kelas eksperimen di SDN 1 Semuli Raya. Hasil penelitian menyatakan bahwa produk LKPD berbasis model pembelajaran AIR yang valid, praktis, dan efektif untuk meningkatkan kemampuan komunikasi matematika peserta didik. Hal ini dibuktikan dari hasil validasi ahli materi, ahli media, dan ahli bahasa dengan kategori "sangat valid". LKPD berbasis model pembelajaran AIR praktis digunakan dengan memenuhi aspek kemenarikan, kemudahan dan bermanfaat dengan kategori "sangat praktis". LKPD berbasis model pembelajaran AIR efektif digunakan dalam meningkatkan kemampuan komunikasi matematika peserta didik pada skor pretest dan posttest dengan hasil perhitungan $\mathrm{N}$-Gain kelas eksperimen masuk pada kategori cukup efektif.
\end{abstract}

Kata Kunci: Komunikasi Matematika, LKPD, Model AIR.

\begin{abstract}
From the results of the answers to the test of mathematical communication skills and the deployment of the questionnaire obtained the problem, namely the low capacity of mathematical communication students, the difficulty of students to write the form of mathematical symbols, and the limitations of teaching materials used during learning in class $\mathrm{V}$ in elementary school. This study aimed to develop valid worksheets of students (LKPD) on building simple spaces in class V elementary school, knowing the practicality of LKPDs from users, educators and students, and knowing the effectiveness of LKPD on increasing mathematical communication skills. The method of development used in this study referred to the research design of Borg and Gall. Data collection techniques were carried out through documentation, observation, questionnaires, and students mathematical communication skills tests. The subjects of this study were 25 control class students and 25 experimental class students at SDN 1 Semuli. The study results stated that LKPD products based on the AIR learning model were valid, practical, and effective in improving students' mathematical communication skills. It was proven by material experts, media experts, and language experts validating results with the "Very Valid" category. LKPD based on AIR learning models was practiced to be used by fulfilling the aspects of attractiveness, convenience, and usefulness with the "very practical" category.
\end{abstract}


LKPD-based AIR learning models were effectively used to improve students' mathematical communication skills in the pretest and post-test scores, with the results of the calculation of the experimental class n-gain entry in the category was quite effective.

Keywords: Mathematical Communication, LKPD, AIR Model.

Received: Agustus 21,2020/ Accepted: Desember 9,2021/ Published Online: Juli 29,2021

\section{PENDAHULUAN}

Dalam pendidikan terdapat pembelajaran yang merupakan proses komunikasi antara pendidik dan peserta didik atau sesama peserta didik. Proses pembelajaran dapat dikatakan berhasil apabila peserta didik mencapai kompetensi yang diharapkan, hal tersebut merupakan Gambaran dari kemampuan peserta didik dalam menguasai suatu materi dalam proses pembelajaran. Tugas pendidik bukan sekedar mengajar yang menjelaskan bahan pengajaran, tetapi juga melatih, membimbing dan memfasilitasi anak didiknya. UU Guru dan Dosen No.14 tahun 2005 menegaskan bahwa guru adalah pendidik profesionalisme dengan tugas utama mendidik, mengajar, membimbing, memfasilitasi, mengarahkan, melatih, menilai dan mengevaluasi peserta didik. Oleh karena itu, proses pembelajaran di dalam kelas tidak didominasi oleh pendidik tetapi melibatkan peserta didik sebagai subjek belajar, sehingga pembelajaran dapat berlangsung dengan baik serta dapat terciptanya pembelajaran yang bermakna. Terdapat $20 \%$ yaitu sekitar 5,1 juta peserta didik di sekolah secara nasional menyatakan sebagian peserta didik tidak memenuhi kompetensi. Sebanyak 20\% inilah yang diduga mengalami learning loss. (Kemendikbud, 2019).

Pembelajaran matematika tidak mengharuskan peserta didik sekedar hafal rumus serta mengerti materi yang dipelajari saat proses pembelajaran, akan tetapi belajar dengan pemahaman serta aktif membangun pengetahuan baru dari pengalaman dan ilmu yang dimiliki sebelumnya sehingga pembelajaran bisa bermakna (Gazali, 2016). Selama ini dalam pelaksanaan pembelajaran matematika di Sekolah Dasar, peserta didik jarang sekali diberi kesempatan untuk mengkomunikasikan ide-idenya. Sehingga peserta didik sulit memberikan penjelasan yang benar, jelas dan logis atas jawabannya, maka perlu diberikan interaksi secara matematis baik secara visual dan verbal. Hal demikian pentingnya peranan kemampuan komunikasi matematika pada pembelajaran matematika perlu untuk dikembangkan.

Sejalan dengan pendapat dari (Samawati \& Rooselyna, 2021) komunikasi merupakan salah satu hal penting dalam proses pembelajaran dan dapat membuat pembelajaran menjadi hidup karena komunikasi merupakan salah satu tujuan yang harus dicapai dalam pembelajaran matematika. Kemampuan komunikasi matematika adalah kemampuan 
seseorang baik secara lisan ataupun tulisan dalam menyampaikan, memahami, dan menerima gagasan/ide matematika dengan cermat, analitis, kritis dan evaluatif untuk meningkatkan pemahaman matematika (Lestari \& Yudhanegara, 2015). Peserta didik harus mampu berinteraksi dan berkomunikasi dengan orang lain, sehingga aspek kemampuan berkomunikasi matematika bisa tercapai. Hal ini sependapat dengan (Hodiyanto, 2017) kemampuan komunikasi matematis individu dapat dikembangkan melalui interaksi lingkungan sosial peserta didik dengan cara mengenal bentuk dan perhitungan matematis seperti bangun ruang, penjumlahan, perkalian dikehidupan sehari-hari.

Berdasarkan hasil studi pendahuluan yang dilakukan di kelas VA SDN 1 Semuli Raya, Kecamatan Abung Semuli Lampung Utara, diketahui bahwa pencapaian kemampuan komunikasi matematika peserta didik pada pembelajaran matematika masih banyak peserta didik yang masuk dalam kategori rendah yaitu sekitar $45 \%$ dari 25 peserta didik kelas VA, hal itu diketahui dari penilaian soal uraian ulangan tengah semester. Peserta didik cenderung malas untuk memahaminya maupun sulit untuk menuliskan dalam bentuk simbol-simbol matematika. Sehingga peranan matematika dalam kemampuan komunikasi matematika pada pembelajaran matematika sangat perlu untuk dikembangkan. Solusi untuk mengatasi hal tersebut yaitu pembelajaran yang selama ini diterapkan pendidik harus diperbaharui guna meningkatkan kemampuan komunikasi matematika peserta didik menjadi lebih baik. Selain itu diperlukan sebuah model pembelajaran yang aktif dan inovatif. Salah satu model pembelajaran yang ditawarkan adalah model pembelajaran Auditory, Intellectually, Repetition (AIR).

Model pembelajaran AIR merupakan variasi dari pembelajaran kooperatif yang menekankan pada 3 aspek yaitu: Auditory (mendengar), Intellectually (berpikir), dan Repetition (pengulangan). Akibat dari 3 hal penekanan tersebut, peserta didikakan memiliki kemampuan lebih dalam pemahaman, kreatifitas, keaktifan dalam pembelajaran, kemampuan pemecahan masalah dan daya ingat (Khadijah \& Sukmawati, 2013). Adapun teori belajar yang mendukung model pembelajaran AIR salah satunya adalah Teori Thorndike salah satunya mengungkapkan the law of exercise (hukum latihan) yang pada dasarnya menyatakan bahwa stimulus dan respon akan memiliki hubungan satu sama lain secara kuat jika proses pengulangan sering terjadi. Semakin banyak kegiatan pengulangan dilakukan maka hubungan yang terjadi akan semakin bersifat otomatis (Fitriana, \& Ismah, 2016).

Bahan ajar yang sering digunakan di sekolah selama ini berupa modul atau buku dari penerbit tertentu. Pembelajaran dengan menggunakan modul memiliki kekurangan berupa biaya yang tinggi, waktu pembelajaran yang lebih lama dan pengawasan yang intens, 
sehingga bahan ajar yang dianggap cocok guna menunjang efektivitas pembelajaran di dalam kelas yang sesuai yaitu menggunakan LKPD sebagai bahan ajar dalam kegiatan pembelajaran yang memudahkan pendidik dalam penyampaian pembelajaran dan peserta didik akan belajar mandiri dan belajar memahami serta menjalankan suatu tugas tertulis. LKPD digunakan untuk mengoptimalkan keterlibatan peserta didik dalam pembelajaran. Secara garis besar LKPD merupakan salah satu sumber pengajaran yang dapat digunakan untuk menunjang kegiatan pembelajaran dengan melibatkan partisipasi peserta didik (Hardiyanti, Sri, \& Cepi, 2020). Sehingga diharapkan dengan menerapkan model pembelajaran AIR pada LKPD yang dikembangkan, peserta didik dapat terlatih berkomunikasi dan menyampaikan ide-idenya melalui diskusi dan kegiatan-kegiatan yang ada pada LKPD kemudian diperkuat dengan tahap repetition yaitu perluasan melalui latihan serta kuis dengan memberikan soal atau permasalahan kemampuan komunikasi matematika.

Selain itu dari hasil wawancara serta penyebaran angket kepada pendidik melalui berbagai cara ada yang secara tatap muka, melalui google form, atau melalui telfon karena terhambat pada masa pandemi ini, didapatkan hasil bahwa adanya keterbatasan bahan ajar di SD Negeri 1 Semuli Raya guna mendukung pembelajaran, pendidik juga menyatakan bahwa LKPD yang digunakan bukan buatan sendiri atau belum dikembangkannya Lembar Kegiatan Peserta Didik (LKPD) melalui model pembelajaran AIR di SD Negeri 1 Semuli Raya, kecamatan Abung Semuli, Lampung Utara, sehingga pendidik setuju bila dikembangkan bahan ajar berupa LKPD berbasis model pembelajaran AIR agar memudahkan peserta didik dalam mempelajari matematika. kemudian peserta didik memiliki kesulitan dalam mempelajari pelajaran matematika, peserta didik juga menyatakan bahwa LKPD yang digunakan belum menarik dalam pembelajaran matematika dan belum dapat membantu peserta didik dalam memecahkan masalah yang ada, sehingga peserta didik membutuhkan bahan ajar alternatif yang dapat digunakan untuk mempelajari matematika secara lebih mudah, menarik dan menyenangkan karena LKPD yang digunakan peserta didik. Di dalam kurikulum 2013, telah disarankan beberapa model pembelajaran yang mengarah pada pengajaran yang berpusat pada peserta didik, salah satunya adalah model pembelajaan AIR. Sehingga LKPD berbasis model pembelajaran AIR dapat diartikan sebagai sebuah bahan ajar tertulis yang didalamnya berisi langkah-langkah kegiatan yang mengacu pada model pembelajaran AIR.

Penelitian terdahulu dari Akerke \& Yessenbolkyzy, (2020); Alifiana, (2021); Ariani. (2017); Fauziah, Winarti, \& Kartono (2017); Handayani, Emi, \& Suhito (2014); Hardiyanti, Sri, \& Cepi, (2020); Johar, Eka, \& Saminan (2018); Kayalar \& Fethi, (2017); Khoshaim 
(2018); Lee, (2015); Pane, Indra, \& Mara, (2018); Shamsi, (2015); Suwarman \& Chandra, (2017); Syahliani, Jamal, \& An'nur, (2014); Triana, Cut, \& Bahrun, (2019); Kurniawan, Tsurayya, \& Ulfah, (2020); Zakiria, Emi, \& Sri (2018). Namun belum ada penelitian sebelumnya yang mengembangkan LKPD berbasis model pembelajaran AIR untuk peserta didik sekolah dasar. Maka penelitian ini akan fokus membahas pengembangan LKPD berbasis AIR berorientasi pada peningkatan komunikasi matematis peserta didik disekolah dasar.

\section{METODE}

Metode penelitian pengembangan yang digunakan dalam penelitian ini mengacu pada desain penelitian Borg \& Gall dengan menerapkan 7 tahap. Subjek yang digunakan pada penelitian ini adalah kelas VA sebagai kelas eksperimen dan VB SDN 1 Semuli Raya, kecamatan Abung Semui, Lampung Utara sebagai kelas kontrol. Kelas eksperimen adalah kelas dimana saat pembelajaran peserta didiknya menggunakan produk yang dikembangkan, sedangkan pada kelas kontrol yaitu peserta didiknya menggunakan bahan ajar yang biasa pendidik gunakan dalam pembelajaran. Tujuan dari penelitian ini yaitu menghasilkan produk LKPD berbasis model pembelajaran AIR yang valid, praktis, dan efektif pada mata pelajaran matematika kelas V SD Negeri 1 Semuli Raya Kecamatan Abung Semuli, Lampung Utara. Untuk kevalidan dengan melakukan validasi yang dinilai dari tiga ahli yaitu 1 ahli materi, 2 ahli media, dan 1 ahli bahasa. Penilaian oleh validator dilakukan pada tahap 3 yaitu pengembangan produk awal.

Para ahli akan menilai LKPD matematika yang akan dikembangkan. Kemudian dilakukan uji coba awal produk dengan penyebaran angket kepada 4 pendidik dan 9 peserta didik di luar sampel yang digunakan yaitu kelas VA SDN 1 Sukamaju Kecamatan Abung Semuli, Lampung Utara. Peserta didik diberikan angket serta LKPD berbasis model pembelajaran AIR yang sudah divalidasi oleh 3 ahli yaitu 1 ahli materi/isi, 2 ahli desain, dan ahli bahasa. Tujuan dilakukan pengisian angket adalah untuk melihat keterbacaan dari produk yang dikembangkan yaitu mengenai kemenarikan produk untuk peserta didik, kemudahan, dan kebermanfaatan. Respon dari pendidik guna mendapatkan penilaian dan saran sehingga bisa di revisi sesuai masukan. Sehingga bisa dilakukan uji lapangan utama untuk melihat keefektifan dari produk yang dikembangkan. Sebelum instrumen tes diberikan kepada peserta didik dilakukan validasi oleh ahli materi untuk menilai kesesuaian soal dengan materi, tingkat kesukaran soal serta disesuaikan dengan karakteristik peserta didik sekolah dasar kelas V. 
Sebelum dilakukan pengujian terhadap hipotesis dilakukan uji persyaratan analisis terlebih dahulu, yaitu uji normalitas dan uji homogenitas. Setelah dilakukan uji normalitas dan uji homogenitas, maka dilanjutkan untuk melakukan uji hipotesis. Uji hipotesis yang digunakan adalah uji independent sample t-test dan uji $N$-Gain. Uji $N$-Gain adalah uji analisis data yang digunakan untuk mengetahui selisih rata-rata pre-test dan post-test masing-masing kelompok kontrol dan eksperimen. Langkah-langkah penelitian ini diadaptasi dari Borg \& Gall (1983) Berikut ini adalah langkah-langkah dari penelitian pengembangan produk yang akan diuji. Langkah-langkah pengembangan yang dilakukan seperti pada Gambar 1 berikut ini.

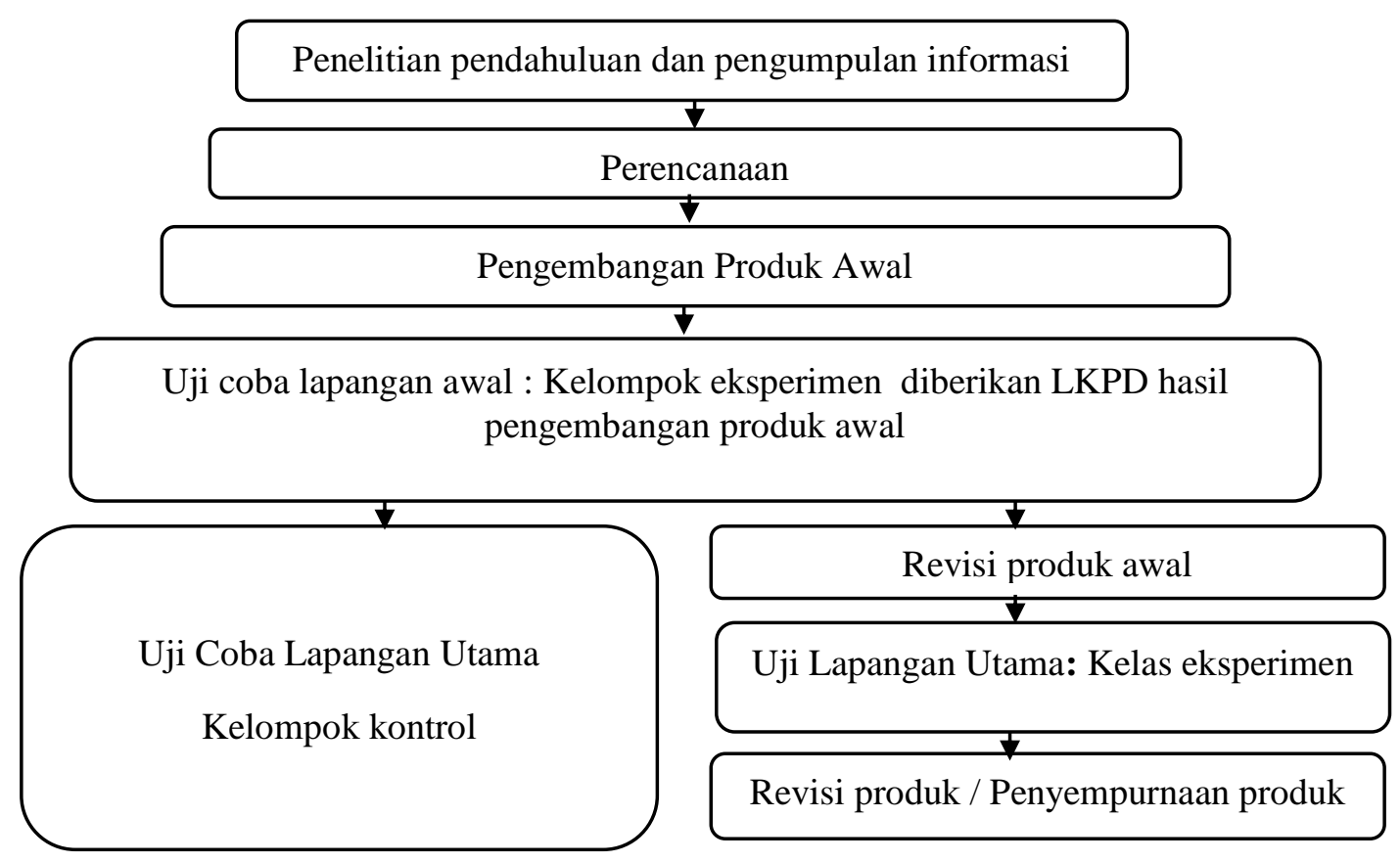

Gambar 1. Langkah-langkah pengembangan yang dilakukan

\section{HASIL PENELITIAN}

Pada penelitian ini bertujuan untuk menghasilkan LKPD berbasis model pembelajaran AIR yang valid, praktis serta efektif untuk pembelajaran matematika kelas V Sekolah Dasar. LKPD yang dikembangkan, dinyatakan valid berdasarkan penilaian para ahli materi, ahli media, dan ahli bahasa. Kemudian dinyatakan praktis digunakan berdasarkan uji coba kepada pendidik dan peserta didik untuk mengetahui respon pengguna LKPD dan dinyatakan efektif berdasarkan tes kemampuan komunikasi yang diujicobakan kepada peserta didik. Berikut hasil yang diperoleh: 


\section{Uji Kevalidan}

Sebelum produk LKPD berbasis model pembelajaran AIR digunakan maka divalidasi terlebih dahulu oleh 3 dosen ahli yaitu ahli materi, ahli media, dan ahli bahasa. Pada uji kevalidan dilakukan pada tahap ke-3 pengembangan Borg \& Gall yaitu tahap pengembangan produk awal. Untuk mendapatkan nilai akhir di gunakan rumus sebagai berikut:

$$
\text { Nilai }=\frac{\text { Jumlah skor yang diperoleh }}{\text { jumlah skor maksimum }} \times 100 \%
$$

Sehingga dari rumus di atas maka diperoleh hasil seperti pada Tabel 1 berikut.

Tabel 1. Rekapitulasi Hasil Uji Validasi Ahli

\begin{tabular}{cccc}
\hline No & Subjek & Aspek Penilaian & Nilai \\
\hline 1. & Validator I & Ahli Materi & $75 \%$ \\
\cline { 1 - 3 } 2. & Validator II & Ahli Desain/Media & \\
\cline { 1 - 3 } 3. & Validator III & Ahli Desain/Media & $86,7 \%$ \\
\hline 4. & Validator IV & Ahli Bahasa & $88,6 \%$ \\
\hline \multicolumn{3}{c}{ Skor Akhir } \\
\hline
\end{tabular}

Berdasarkan Tabel 1, hasil penelitian oleh ahli materi diperoleh persentase sebesar $75 \%$ dengan kriteria valid, ahli media diperoleh persentase sebesar 86,7\% dengan kriteria sangat valid, dan ahli bahasa diperoleh persentase sebesar 88,6\% dengan kriteria sangat valid. Sehingga diperoleh rata-rata nilai validasi ahli sebesar 83,4 dengan kategori sangat valid. Adapun saran-saran dari validator materi, desain/media, dan bahasa sebagai berikut: Setiap selesai pembelajaran diberi latihan soal untuk mengetahui perkembangan peserta didik, Gambar yang digunakan sebagai ilustrasi bangun ruang sebaiknya menggunakan benda yang sering dijumpai peserta didik di kehidupan sehari-hari, Perbaiki petunjuk penggunaan LKPD, Aktivitas belajar peserta didik pada LKPD menekankan pada pengembangan komunikasi matematika, Tulisan pada judul sampul LKPD menggunakan huruf balok resmi supaya tidak salah persepsi, Warna dasar pada sampul LKPD lebih disesuaikan dengan anak kelas V sehingga lebih menarik perhatian peserta didik untuk membaca dan memahaminya, Perbaiki pilihan kata dan tanda baca yang belum sesuai.

\section{Uji Kepraktisan}

Setelah produk LKPD berbasis model pembelajaran AIR selesai pada tahap pengembangan maka selanjutnya adalah menguji kepraktisan LKPD yang dikembangkan oleh pengguna yaitu peserta didik dan pendidik. Pada uji kepraktisan dilakukan pada tahap ke-4 
pengembangan Borg \& Gall yaitu tahap pengembangan produk awal dan dilanjutkan tahap ke-5 yaitu revisi produk. Uji kepraktisan produk dilakukan dengan memberikan angket penilaian mengenai kemenarikan, kemudahan, serta kebermanfaatan LKPD. Berikut hasil yang didapatkan pada uji coba pendidik.

Uji coba untuk pendidik dilakukan dengan sampel uji coba sebanyak 4 orang pendidik matematika kelas $\mathrm{V}$ dari masing-masing sekolah. Tabel 2 berikut ini adalah hasil rekapitulasi penilaian yang didapatkan:

Tabel 2. Rekapitulasi Uji Kepraktisan bagi Pendidik

\begin{tabular}{lcl}
\hline \multicolumn{1}{c}{ Aspek } & $\begin{array}{c}\text { Skor per } \\
\text { Aspek }\end{array}$ & \multicolumn{1}{c}{ Kriteria } \\
\hline Kemenarikan & $92,12 \%$ & Sangat menarik \\
\hline Kemudahan & $90,18 \%$ & Sangat mudah \\
\hline Kebermanfaatan & $93,75 \%$ & Sangat bermanfaat \\
\hline Rata-rata Persentase & \multicolumn{2}{c}{$\mathbf{9 2 , 0 2 \%}$} \\
\hline \multicolumn{1}{c}{ Kriteria } & \multicolumn{2}{c}{ Sangat Praktis } \\
\hline
\end{tabular}

Berdasarkan Tabel 2, produk LKPD yang dikembangkan mencapai persentase 92,02\% dengan kriteria sangat praktis.

Selanjutnya uji coba untuk peserta didik untuk melihat uji kepraktisan peserta didik dilakukan sebanyak dua kali yaitu saat uji coba awal sebanyak 9 peserta didik dan uji kedua setelah selesai pembelajaran menggunakan LKPD berbasis model pembelajaran AIR yaitu kepada 25 peserta didik kelas eksperimen. Hasil respon angket peserta didik terhadap LKPD berbasis model pembelajaran AIR dapat dilihat pada Tabel 3 dan Tabel 4.

Tabel 3. Rekapitulasi Uji Kepraktisan Kelompok Kecil

\begin{tabular}{lcl}
\hline \multicolumn{1}{c}{ Aspek } & $\begin{array}{c}\text { Skor Per } \\
\text { Aspek }\end{array}$ & \multicolumn{1}{c}{ Kriteria } \\
\hline Kemenarikan & $88,89 \%$ & Sangat menarik \\
\hline Kemudahan & $84,52 \%$ & Sangat mudah \\
\hline Kebermanfaatan & $84,02 \%$ & Sangat bermanfaat \\
\hline Rata-rata Persentase & \multicolumn{2}{c}{$\mathbf{8 5 , 8 1 \%}$} \\
\hline \multicolumn{1}{c}{ Kriteria } & \multicolumn{2}{c}{ Sangat Praktis } \\
\hline
\end{tabular}

Berdasarkan Tabel 3, produk LKPD yang dikembangkan mencapai persentase $85,81 \%$ dengan kriteria sangat praktis untuk uji coba 9 peserta didik.

Tabel 4. Rekapitulasi Uji Kepraktisan Kelompok Besar

\begin{tabular}{lcl}
\hline \multicolumn{1}{c}{ Aspek } & $\begin{array}{c}\text { Skor Per } \\
\text { Aspek }\end{array}$ & \multicolumn{1}{c}{ Kriteria } \\
\hline Kemenarikan & $89,75 \%$ & Sangat menarik \\
\hline Kemudahan & $86,71 \%$ & Sangat mudah \\
\hline Kebermanfaatan & $93 \%$ & Sangat bermanfaat \\
\hline
\end{tabular}


e-ISSN : 2656-7245 Pengembangan LKPD Berbasis Model Pembelajaran AIR Berorientasi ...

\begin{tabular}{cc}
\hline Rata-rata Persentase & $\mathbf{8 9 , 8 2 \%}$ \\
\hline Kriteria & Sangat Praktis \\
\hline
\end{tabular}

Kemudian pada Tabel 4 untuk uji kepraktisan kelas utama 25 peserta didik mencapai persentase $89,82 \%$ dengan kriteria sangat praktis. Hal tersebut menunjukkan bahwa LKPD berbasis model pembelajaran AIR menurut respon peserta didik sangat praktis untuk digunakan dalam pembelajaran.

\section{Uji Keefektifan}

Pada uji keefektifan LKPD yang dikembangkan, yaitu dengan melihat hasil pretest dan posttest kemudian melihat perbedaan antara kelas kontrol dan kelas eksperimen. Pada uji keefektifan dilakukan pada tahap ke-6 pengembangan Borg \& Gall yaitu tahap uji lapangan utama yang melibatkan seluruh peserta didik kelas VA sebagai kelas eksperimen dan kelas VB sebagai kelas kontrol. Sebelumnya dilakukan pengujian persyaratan analisis yaitu uji normalitas dan uji homogenitas. Uji Normalitas bertujuan untuk menguji apakah data variabel independen mempunyai distribusi normal atau tidak. Data yang baik adalah memiliki distribusi data normal atau mendekati normal. Berikut hasil yang didapatkan dapat dilihat pada Tabel 5 berikut.

Tabel 5. Normalitas Data Penilaian Kemampuan Komunikasi Matematis

\begin{tabular}{|c|c|c|c|c|c|c|c|}
\hline \multicolumn{8}{|c|}{ Tests of Normality } \\
\hline & \multirow[t]{2}{*}{ Kelas } & \multicolumn{3}{|c|}{$\begin{array}{l}\text { Kolmogorov- } \\
\text { Smirnov }^{\mathrm{a}}\end{array}$} & \multicolumn{3}{|c|}{ Shapiro-Wilk } \\
\hline & & Statistic & Df & Sig & Statistic & Df & Sig. \\
\hline \multirow{6}{*}{$\begin{array}{l}\text { Kemampuan } \\
\text { komunikasi } \\
\text { matematis }\end{array}$} & Pre-Test Kelas & , 129 & 25 & ,20 & ,978 & 25 & ,839 \\
\hline & $\begin{array}{l}\text { Eksperimen (Model } \\
\text { Pembelajaran AIR) }\end{array}$ & & & $0^{*}$ & & & \\
\hline & Post-Test Kelas & , 152 & 25 &, 14 & ,963 & 25 & ,479 \\
\hline & $\begin{array}{l}\text { Eksperimen (Model } \\
\text { Pembelajaran AIR) }\end{array}$ & & & 2 & & & \\
\hline & $\begin{array}{l}\text { Pre-Test } \\
\text { KelasKontrol } \\
\text { (Pembelajaran } \\
\text { Konvensional) }\end{array}$ & , 156 & 25 & $\begin{array}{r}11 \\
8\end{array}$ & ,923 & 25 & ,061 \\
\hline & $\begin{array}{l}\text { Post-Test Kelas } \\
\text { Kontrol } \\
\text { (Pembelajaran } \\
\text { Konvensional) }\end{array}$ & , 102 & 25 & $\begin{array}{r}, 20 \\
0^{*}\end{array}$ & ,948 & 25 & ,231 \\
\hline
\end{tabular}


Berdasarkan Tabel 5 uji normalitas yang telah dilakukan dengan menggunakan uji normalitas Kolmogorov-Smirnov dan Shapiro wilk hasil analisis uji normalitas data kelas eksperimen maupun kelas kontrol diperoleh nilai Sig. lebih besar dari level of significant 5\% $(>0,050)$. Hal ini berarti data yang digunakan pada penelitian ini terdistribusi secara normal. $\underline{\text { Tabel } 6}$ berikut hasil uji homogenitas.

Tabel 6. Homogenitas Data Penilaian Kemampuan Komunikasi Matematis

\begin{tabular}{|c|c|c|c|c|c|}
\hline \multicolumn{6}{|c|}{ Test of Homogeneity of Variance } \\
\hline & & $\begin{array}{l}\text { Levene } \\
\text { Statistic }\end{array}$ & $\mathrm{df}_{1}$ & $\overline{\mathrm{df}_{2}}$ & Sig. \\
\hline \multirow{4}{*}{$\begin{array}{l}\text { Kemapuan } \\
\text { Komunikasi } \\
\text { matematis }\end{array}$} & Based on Mean & ,795 & 3 & 96 &, 153 \\
\hline & Based on Median & 613 & 3 & 96 & ,191 \\
\hline & $\begin{array}{l}\text { Based on Median } \\
\text { and with adjusted } \\
\text { df }\end{array}$ & ,613 & 3 & 87,558 & ,192 \\
\hline & $\begin{array}{l}\text { Based on trimmed } \\
\text { mean }\end{array}$ & ,792 & 3 & 96 &, 154 \\
\hline
\end{tabular}

Berdasarkan Tabel 6, hasil analisis uji homogenitas dapat disimpulkan bahwa data sampel berasal dari populasi homogen karena nilai Sig. lebih besar dari 0,05. Setelah memenuhi syarat maka dilakukan pengujian hipotesis melalui uji independent sample t-test untuk mengetahui perbedaan signifikan antara kedua kelompok tersebut dan menghitung nilai $\mathrm{N}$-Gain. Normalized gain (N-Gain) adalah uji analisis data yang bertujuan untuk mengetahui efektivitas terhadap penggunaan LKPD berbasis model pembelajaran AIR.

Dalam menentukan atau mengetahui tingkat efektifitas dari produk, seperti pada Tabel $\underline{7}$ berikut ini.

Tabel 7. Kategori Tafsiran Efektivitas $N$-gain

\begin{tabular}{cc}
\hline Persentase (\%) & Kategori \\
\hline$<40$ & Tidak efektif \\
\hline $40-45$ & Kurang efektif \\
\hline $56-75$ & Cukup efektif \\
\hline$>76$ & Efektif \\
\hline
\end{tabular}

Sumber: Hake (1999)

Berdasarkan perhitungan efektivitas diperoleh hasil uji N-Gain seperti terlihat pada Tabel 8 berikut ini. 
Tabel 8. Hasil Rata-rata N-Gain

\begin{tabular}{cccc}
\hline No & Kelas & $\boldsymbol{N}$-Gain(\%) & Klasifikasi Efektif \\
\hline 1 & Kelas VA (Eksperimen) & 67,86 & Cukup efektif \\
\hline 2 & Kelas VB (Kontrol) & 32,68 & Tidak efektif \\
\hline
\end{tabular}

Berdasarkan Tabel 8, diperoleh persentase n-gain pada kelas eksperimen sebesar $67,86 \%$ termasuk dalam kategori cukup efektif, sedangkan persentase $n$-gain pada kelas kontrol sebesar 32,68\% termasuk dalam kategori tidak efektif. Kemudian pengujian hipotesis dilakukan dengan menguji uji-t (Independent sample t-test) atau uji beda rata-rata terhadap hasilpretest dan posttest peserta didik. Proses perhitungan koefisien t pada independent sample t-test ini menggunakan bantuan Program SPSS 25.0 Tabel 9 berikut ini penafsiran uji-t yang telah dilakukan:

Tabel 9. Hasil Uji Independent Sample T-Test

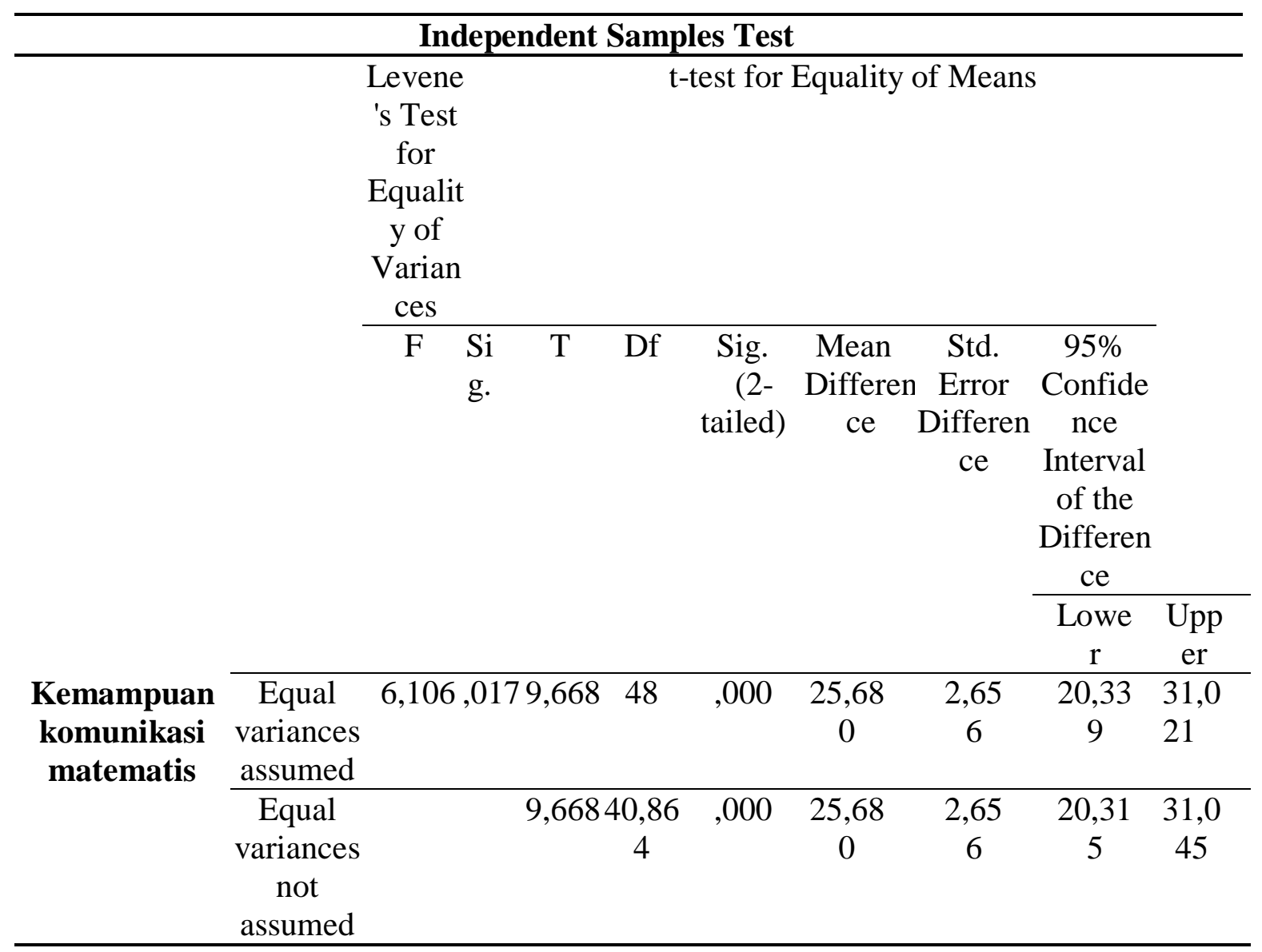

Berdasarkan Tabel 9, hasil perhitungan uji perbedaan dua rata-rata data yang disajikan terlihat bahwa nilai Significant (2-tailed) sebesar 0,000 lebih besar dari level of significant 5\% $(0,000>0,050)$. Dengan demikian dapat disimpulkan bahwa terdapat perbedaan rata-rata antara kelompok peserta didik yang mendapatkan perlakuan dengan menggunakan LKPD Berbasis model pembelajaran AIR (kelas VA) dengan kelompok peserta didik yang dalam 
proses pembelajaran tidak menggunakan LKPD berbasis model pembelajaran AIR (kelas VB). Dari hasil analisis di atas menunjukkan bahwa $\mathrm{H}_{\mathrm{O}}$ di tolak, karena taraf signifikansi Sig. (2tailed) sebesar $0,000<0,05$, sedangkan $\mathrm{H}_{1}$ diterima karena terdapat perbedaan yang signifikan antara peningkatan kemampuan komunikasi matematis peserta didik kelas eksperimen dengan kelas kontrol.

\section{PEMBAHASAN}

Hasil penelitian dan pengembangan LKPD berbasis model pembelajaran AIR dinyatakan valid, praktis, dan efektif untuk meningkatkan kemampuan komunikasi matematika peserta didik. Dibuktikan dengan hasil nilai rata-rata dari ahli materi, ahli media, dan ahli bahasa sebesar 83,4\% dengan kategori "sangat valid". Tiga aspek yaitu aspek materi LKPD, aspek media LKPD dan aspek bahasa/keterbacaan. Penilaian dilakukan dengan pengisian angket sesuai aspek yang dinilai. Uji Kepraktisan diperoleh rata-rata penilaian respon pendidik terhadap LKPD dari ketiga aspek sebesar 92,04\% dengan kategori sangat Praktis. Pada uji kepraktisan peserta didik dilakukan sebanyak dua kali yaitu saat uji coba awal sebanyak 9 peserta didik dan uji kedua setelah selesai pembelajaran menggunakan LKPD berbasis model pembelajaran AIR yaitu kepada 25 peserta didik kelas eksperimen.

Uji Efektivitas diperoleh data hasil belajar peserta didik meningkat pada pretest dan posttest. Diperoleh hasil bahwa rata-rata $\mathrm{N}$-Gain kelas eksperimen lebih tinggi dari kelas kontrol. Pada kelas eksperimen nilai rata-rata $\mathrm{N}$-Gain sebesar $68 \%$ dan kelas kontrol sebesar $33 \%$. Sehingga dapat ditarik kesimpulan bahwa produk yang dikembangkan efektif dalam meningkatkan kemampuan komunikasi matematika peserta didik. Beberapa penelitian yang relevan terkait dengan pengembangan LKPD berbasis model pembelajaran AIR pada penelitian Kurniawan, Tsurayya, \& Ulfah, (2020) menjelaskan bahwa penggunaan LKPD dapat memfasilitasi kemampuan komunikasi matematika peserta didik. Bahan ajar tersebut menarik dan dapat menimbulkan motivasi belajar di tengah keterbatasan bahan ajar dan waktu dalam kelas. Suwarman \& Chandra (2017); Syahliani, Jamal, \& An'nur (2014); Hardiyanti, Sri, \& Cepi, (2020); Handayani, Emi, \& Suhito (2014); menjelaskan bahwa pembelajaran dengan model pembelajaran AIR lebih baik dibandingkan dengan kelas dengan pembelajaran konvensional. Hal ini ditunjukkan dari peningkatan kemampuan komunikasi matematika serta hasil belajar peserta didik. Penelitian lain yang berkaitan dengan model pembelajaran AIR dan kemampuan komunikasi matematika yaitu penelitian oleh Johar, Eka, \& Saminan (2018); Fauziah, Winarti, \& Kartono (2017); Zakiria, Emi, \& Sri (2018); Triana, Cut, \& Bahrun (2019); Lee (2015); Kayalar \& Fethi (2017); dan Shamsi (2015) menjelaskan bahwa 
penerapan model pembelajaran kooperatif salah satunya model pembelajaran Auditory Intellectualy Repatition serta dibutuhkannya strategi pembelajaran yang mampu meningkatkan hasil belajar, kemampuan bernalar, dan kemampuan komunikasi matematika peserta didik.

Kegiatan repetition (pengulangan) pada model pembelajaran AIR dapat melatih peserta didik dalam menyelesaikan berbagai bentuk persoalan dan memiliki ide-ide serta cara sendiri untuk memecahkan permasalahannya. Sehingga kemampuan komunikasi matematis serta hasil belajar peserta didik dapat meningkat. Hal ini sesuai dengan teori belajar yang mendukung model pembelajaran AIR salah satunya adalah teori Thorndike salah satunya mengungkapkan the law of exercise (hukum latihan) yang pada dasarnya menyatakan bahwa stimulus dan respon akan memiliki hubungan satu sama lain secara kuat jika proses pengulangan sering terjadi. Penelitian yang relevan yang mendukung yaitu Pane, Indra, \& Mara, (2018); Ariani (2017); Akerke \& Yessenbolkyzy (2020); Khoshaim (2018); serta penelitian yang telah dilakukan, bahwasanya dengan dikembangkan LKPD berbasis model pembelajaran AIR dapat menghasilkan pembelajaran yang lebih baik terbukti dengan hasil pretest dengan postest mengalami peningkatan. Hasil nilai kemampuan komunikasi matematika posttest lebih tinggi dibanding pretest. Ini menandakan bahwa pengaruh penggunaan LKPD berbasis model pembelajaran AIR terbukti dapat meningkatkan kemampuan komunikasi matematika peserta didik.

Penelitian terdahulu tersebut juga sejalan dengan hasil penelitian ini, sehingga adanya LKPD berbasis model pembelajaran AIR ini dapat dijadikan sebuah alternatif dari keterbatasan bahan ajar di SD Negeri 1 Semuli Raya guna mendukung pembelajaran pada materi bangun ruang sederhana (balok dan kubus). Selain itu juga, LKPD diharapkan dapat membantu pendidik dalam mencapai indikator dan tujuan pembelajaran. Memotivasi pendidik menjadi lebih kreatif dalam membuat pendamping bahan ajar. LKPD berbasis model pembelajaran AIR ini juga diharapkan dapat digunakan peserta didik untuk belajar secara mandiri. Selain itu juga apabila peserta didik ingin belajar secara berkelompok maka akan tercipta suasana kegiatan berdiskusi yang baik dan lebih terarah dalam menyelesaikan suatu permasalahan.

Perubahan tampilan LKPD setelah dilakukan validasi oleh para ahli dan saran dari pendidik. Berikut ini merupakan contoh hasil perubahan tampilan LKPD dari sebelum dan sesudah diperbaiki baik dari validasi ahli materi, ahli media, dan ahli bahasa seperti yang terlihat pada Gambar 2 berikut ini. 

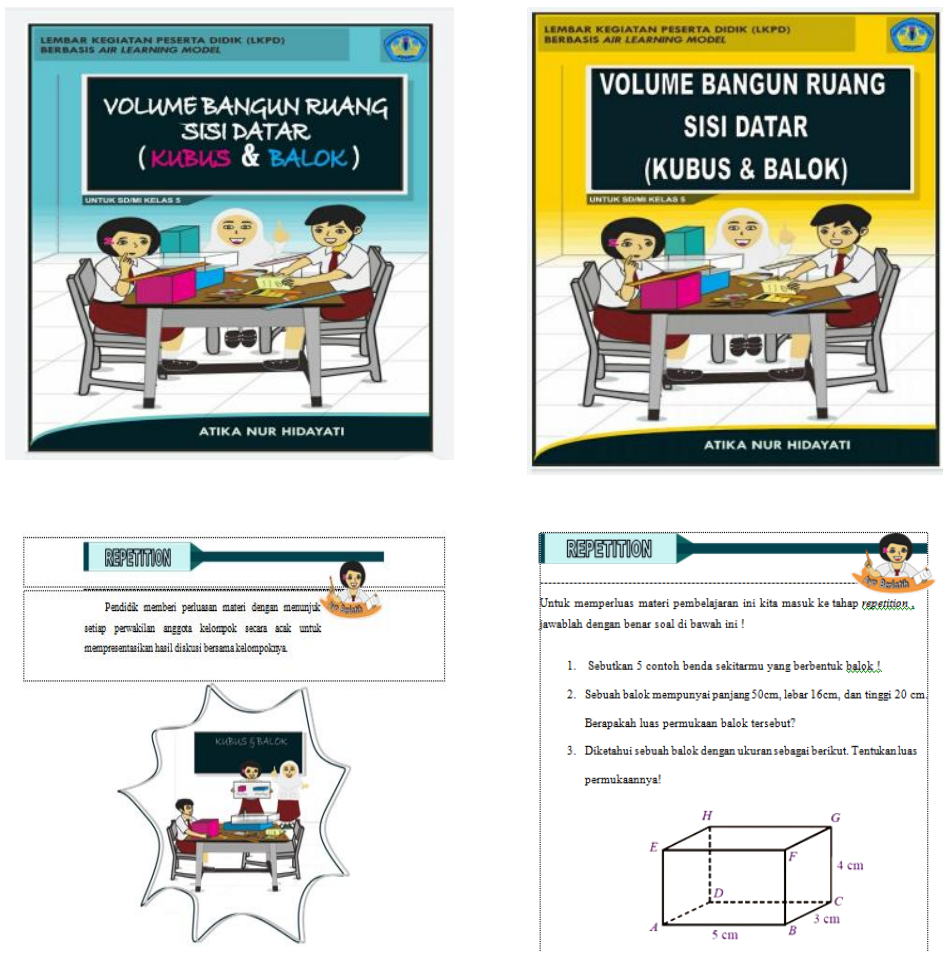

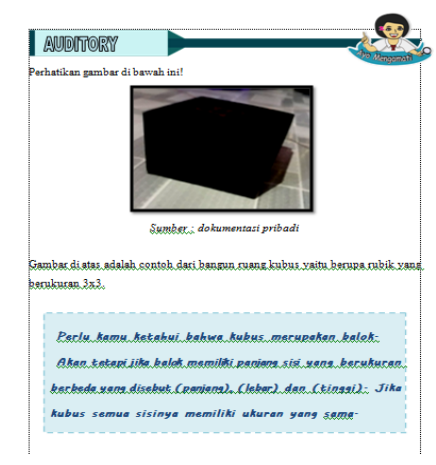

Sebelum Revisi

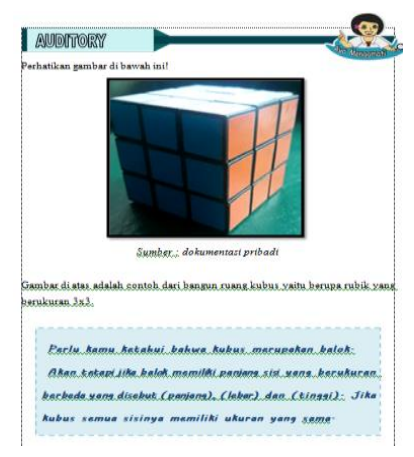

Setelah Revisi

Gambar 2. Tampilan LKPD Sebelum dan Sesudah Revisi

\section{SIMPULAN}

Berdasarkan hasil penelitian dan pengembangan yang telah dilaksanakan dapat disimpulkan bahwa: 1). Produk LKPD berbasis model pembelajaran AIR yang dikembangkan valid digunakan untuk pembelajaran matematika kelas V SD dengan materi bangun ruang sederhana (kubus dan balok). Produk penelitian ini telah divalidasi oleh ahli materi, ahli media, dan ahli bahasa. 2). Produk LKPD berbasis model pembelajaran AIR yang dikembangkan praktis digunakan untuk pembelajaran matematika kelas V SD dengan materi bangun ruang sederhana (kubus dan balok). Hal ini dibuktikan dengan perolehan penilaian instrumen yang ditujukan untuk pendidik dan peserta didik. 3). Produk LKPD berbasis model pembelajaran AIR yang dikembangkan efektif dalam meningkatkan kemampuan komunikasi 
matematis peserta didik. Hal ini dibuktikan dengan adanya perbedaan perolehan $n$-gain yang diperoleh peserta didik melalui pretest dan posttest sebelum dan sesudah proses pembelajaran menggunakan produk LKPD berbasis model pembelajaran AIR kemudian melalui uji-t didapat hasil terdapat perbedaan signifikan antara kelas kontrol dan kelas eksperimen.

\section{REFERENSI}

Akerke, Y., \& Yessenbolkyzy, A. (2020). The role of repetition in learning math. Proceedings of IYSW, 9 (1), 213-222.

Ariani, D.N. (2017). Strategi Peningkatan Kemampuan Komunikasi Matematis Siswa SD/MI. Jurnal Madrasah Ibtidaiyah (Muallimuna), 3(1), 96-107.

Borg, W.R., \& Gall, M.D. (1983). Educational Research: An Introduction. New York: Longman.

Fauziah, F., Winarti, E., \& Kartono, K. (2017). The Effectiveness of SAVI Learning in Achieving Communication Ability and Mathematical Disposition for Eighth Grader. Unnes Journal of Mathematics Education, 6(1), 1-9.

Fitriana, M., \& Ismah, I. (2016). Pengaruh model pembelajaran auditory intellectually repetition terhadap hasil belajar matematika siswa ditinjau dari kedisiplinan siswa. FIBONACCI: Jurnal Pendidikan Matematika dan Matematika, 2(1), 59-68.

Gazali, R. Y. (2016). Pembelajaran matematika yang bermakna. Math Didactic: Jurnal Pendidikan Matematika, 2(3), 181-190.

Hake, R, R. (1999). Analyzing Change/gain Score. [Online] Tersedia:http://www.physics.indiana.edu/ nsdi/AnalyzingChange-Gain.pdf [Diakses 3 Maret 2021.

Handayani, I.E., Emi, P., \& Suhito. (2014). Keefektifan Auditory Intellectually Repetition Berbantuan LKPD terhadap Kemampuan Penalaran Peserta Didik SMP. Kreano, Jurnal Matematika Kreatif-Inovatif, 5(1), 1-9.

Hardiyanti, P.C., Sri,W., \& Cepi, K. (2020). Efforts to Increase Mathematical Logical Intelligence Through Development of Student Worksheets Based on Problem Based Learning. Journal of Innovative Science Education (JISE), 9(3), 335-341.

Hodiyanto. (2017). Kemampuan Komunikasi Matematis dalam Pembelajaran Matematika. Admathedu, 7(1), 9-17.

Johar, R., Eka, J., \& Saminan. (2018). Students' Mathematical Communication Ability and Self-Efficacy using Team Quiz Learning Model. International Journal on Emerging Mathematics Education (IJEME), 2(2), 203-214.

Kayalar, F., \& Fethi, K. (2017). The effects of Auditory Learning Strategy on Learning Skills of Language Learners (Students' Views). Journal Of Humanities And Social Science (IOSR-JHSS), 22(10), 4-10. 
Kemendikbud. (2019). Hasil PISA Indonesia 2018: Akses Makin Meluas, Saatnya Tingkatkan Kualitas. Diakses pada 7 Maret 2021, dari https://www.kemdikbud.go.id/main/blog/2019/12/hasil-pisa-indonesia-2018-akses-makinmeluas-saatnya-tingkatkan-kualitas

Khadijah, S.,\& Sukmawati.,A.R. ((2013). Efektivitas Model Pembelajaran Audiotory Intellectually Repetition dalam Pengajaran Matematika di Kelas VII MTs. Edu-Mat: Jurnal Pendidikan Matematika, 1(1), 68-75.

Khoshaim, H. B. (2018). Inattentive Students Errors in Mathematics: Alarming Repetition. International Journal of Learning, Teaching and Educational Research. 17(11), 135153.

Kurniawan, Y., Tsurayya, A., \& Ulfah, S. (2020). Pengembangan Lembar Kerja Peserta Didik Untuk Meningkatkan Kemampuan Komunikasi Matematik Peserta Didik SMP. Jurnal silogisme: Kajian Ilmu Matematika dan Pembelajarannya, 4(2), 74-80.

Lee, J. (2015). Oh, I just had it in my head": Promoting Mathematical Communications in Early Childhood". Contemporary Issues in Early Childhood. 16(3), 284-287.

Lestari, K.E \& Yudhanegara. (2015). Penelitian Pendidikan Matematika. Bandung: PT Refika Aditama.

Pane, N,S., Indra, J., \& Mara, S, L. (2018). Analisis Kemampuan Komunikasi Matematis Siswa Pada Materi Penyajian Data Di Kelas VII MTs Islamiyah Medan. AXIOM, 7(1), hlm.97-109.

Samawati, I., \& Rooselyna, E. (2021). Students' Mathematical Communication Skills In Solving Story Problems Based On Mathematical Abilities. International Journal of Indonesian Education and Teaching (IJIET), 5(1), 61-72.

Shamsi, A.F. (2015). A Theoretical Study About Motivating Auditory Learners. Electronic International Journal of Education, Arts, and Science (EIJEAS), 1(1), hal.28-34.

Suwarman, R.F., \& Candra, A.A. (2017). Pengaruh Model Auditory Intellectualy Repetition (AIR) terhadap Peningkatan Pemecahan Masalah. PRISMA, 6(2), 153-161.

Syahliani, M., Jamal, M. A., \& An'nur, S. (2014). Penerapan Model Pembelajaran Auditory Intelectually Repetition (AIR) Untuk Meningkatkan Hasil Belajar Siswa. Berkala Ilmiah Pendidikan Fisika, 2(3), 213-221.

Triana, M., Cut, M.Z., \& Bahrun. (2019). Students' Mathematical Communication Ability through the Brain-Based Learning Approach using Autograph. Efektor, 6(1), 61-67.

Zakiria, I,K., Emi, P., \& Sri, N,A. (2018). The mathematical Communication Ability Based on Gender Difference on Students of XI Grade by Using Problem Based Learning Model Assisted by Probing Prompting Technique. Unnes Journal of Mathematics Education (UJME).7(2), 78-84. 